\title{
Freelancing, translating, observing: Association4U case study
}

\author{
Elina Paliichuk* \\ Borys Grinchenko Kyiv University, Institute of Philology, 18/2 Bulvarno-Kudriavska Str, Kyiv, Ukraine, 04212
}

\begin{abstract}
The paper presents an overview of the freelance practice in the Ukrainian translation industry through the lens of the role of Associate Translation Fellow at "Association4U" EU-funded technical aid project (Phase I) aimed at supporting approximation of Ukrainian laws to EU legislation. To meet the challenges of the ever-changing political world, translators should be able to build specific capacities. Under the microscope of the observations made is the range of competences which a contemporary translator should have to maintain a competitive profile in institutional translation domain. An institutional translator's portrait has been drawn up based on the $\mathrm{A} 4 \mathrm{U}$ case, which became possible due to feedbacks given to junior fellows and stylistic analysis of the translated texts. The studies of acquis communautaire provide insights into the stylistic peculiarities of translation of the EU acts in the context of the Ukrainian language. Key attention is given to cognitive, stylistic, and discursive aspects of translation process. The paper deals with a complex of the general philological background and specific skills of translation experts, which is a prerequisite of accurate translation in the framework of academic, industrial, and institutional realms.
\end{abstract}

\section{Introduction}

The challenges a Ukrainian translator faces today call for new vision of the profession. A more flexible approach should be taken nowadays, which implies various forms of cooperation between representatives of the industry: translation agency top manager, project manager, translator and proofreader. The European integration endeavours of Ukraine necessitate a specific matrix of translator's competences embracing not only linguistic knowledge but also legal and specific sectoral expertise. In Ukraine, the traditional employment form (e.g. in-house translator) is being more frequently replaced with self-employment, or freelancing, which is a widespread practice of translation services provision both to businesses and institutions. Freelancing means doing certain amount of works without concluding a long-term employment agreement at the national or foreign market, where a translator usually acts as private entrepreneur in the capacity of contractor to translation services agreement concluded directly with customers. Such type of employment enables translators to vary roles depending on personal interests or customers' needs: translator or proofreader as a fellow at international projects, consultant on translation and general linguistic issues, project manager.

With increasing demand for linguistic services, translators, registered as private entrepreneurs, may set up their own companies, positioning themselves as owners or co-founders of translation business. Yet, this role neither restricts their potential integration into other companies (for instance, as project managers or subcontractors depending on their career and economic interests) nor excludes their joining various international technical aid projects as translation experts or consultant, junior, associate, or senior translation fellows. At the same time, new roles may arise from situational associations of freelancers acting as partners for performance of an economically viable project. Whatever the role is, be it an independent operator in the translation market or the one who works within the system of contractors at any organisation, this does not exclude the possibility of professional development in academic setting. Thus, scientist, researcher, lecturer, or sectoral expert are the roles extending the professional portrait of translators and enhancing their competitiveness at labour market. The ability to shift roles suggests translators have such soft skills as flexibility, workload planning, time management, resilience, readiness to be supervised and to supervise others. This "fluid" attitude towards the translation job implies that professionals should have an ability to perform tasks in various capacities, which extends their possibility to acquire new knowledge and observe the processes from various perspectives. The flexible approach to translators' roles implies that the potential to apply practical and theoretical knowledge is not limited to specific positions, and this gives translators an opportunity to take over several short-term positions at a given time.

At the same time, a strategic European integration course of Ukraine as an independent and sovereign State [1] necessitates initiation and vigorous growth of joint technical aid projects in various sectors of vital activity of the country: economy, education, culture, ecology, energy, finance, transport, public health, municipal governance. The signing of the Association Agreement and DCFTA between Ukraine and the European Union in March and June 2014 requires from

\footnotetext{
${ }^{*}$ Corresponding author: e.paliichuk@kubg.edu.ua
} 
Ukraine to ensure bringing the Ukrainian regulatory framework in line with the EU legislation. This means the necessity to rethink existing and operative regulatory acts of Ukraine, to develop new laws and fill the legislation lacunas in certain areas. To meet these objectives, Ukraine needs not only professional efforts to be made by legal experts for comparative analysis of EU and Ukrainian legislation, but also comprehensive competences of the translators outsourced at international projects, their awareness of operation and functioning of EU institutions, state of affairs in the markets of Member States, and additional sectoral knowledge.

In response to the challenges the Ukrainian governmental institutions face today in the process of reforming various sectors and spheres of public activity and bringing Ukrainian legislation in line with EU standards, the Association4U Project was organised. Its activity was aimed at supporting implementation of the Association Agreement. One of the key areas of the Project was Component I, aimed at legal approximation and policy implementation, which was achieved through the system of certified high quality translations. This necessitated building the standardised Ukrainian sublanguage for translation on the basis of specific jurilinguistic competences, including sectoral expertise and translation technologies. The state policy and mechanism for adaptation is detailed in the Law of Ukraine "On the State Program for Adaptation of Ukrainian Legislation to the Legislation of the European Union" 1629-IV revised November 4, 2018 [2].

Consequently, such translation challenges called for mobilising professional human resources not only in the framework of legal science and practice, but also in terms of sectoral expertise in order to take the peculiar features of national markets operation into account.

A crucial role was performed by translators whose comprehensive linguistic competence was a key success factor of meeting the objectives. Their understanding of how the European Union was established and how it functions, awareness of the state of affairs within sectoral domains of EU common markets, and the ability to explore the common features and differences across EU markets ensured high quality performance and required deliverables. These competences are the components of an Assocition4U fellow professional portrait.

Therefore, this paper provides insights into the institutional translation process in Ukraine in terms of its organisation, general stylistic features and linguistic problems resolved in the process of dealing with EU legal texts and editing the translations prepared by junior fellows. The case-study embraces the experience of participation in the First Phase of Association4U Project (technical aid project funded by European Union: EuropeAid/137074/DH/SER/UA), described as seen by the Associate Translation Fellow, with the focus on the competences acquired for over two-year cooperation with the grant-holding organisation (GFA Consulting Group $\mathrm{GmbH}$ ). This personal engagement with the Project was predetermined by the heart set on the possibility to make a significant contribution to enhancing the capacities of Ukrainian government institutions in comprehensive implementation of their commitments under the EU-UA Association Agreement (in the framework of EU-funded Project Association4U).

\section{Methods}

The methodology used in this paper embraces such qualitative methods as literature review [3] and observations made with a focus on cognitive aspects of translation process, discursive nature, and stylistic peculiarities of the EU legal texts.

The object is twofold: linguistic features of EU documents and the translation processes. The former refers to the verbal arrangement of translation as a product, which is predetermined by linguistic peculiarities of EU-documents. The latter concerns ensuring high quality translation activities seen as a cycle of "translation-proofreading-revisionterminological expertise", in the context of interaction and communication between fellows at all levels of the project. Due to the practice of translating and proofreading, and, occasionally, providing revision of the previously translated and proofread texts, such observations focused on cognitive, discursive, and stylistic aspects of the EU acts.

The literature review made provides for the findings about general linguistic features of EU legal acts based on the works of European scholars [4-7]. This analysis is valuable for Ukrainian translators as it helps to align the style of the Ukrainian language translation with "a pan-European text genre" [4].

The observation method was applied as a research technique at all stages of implementation of the Project, both when performing translation-related assignments and when discussing some results within A4U team. For instance, to meet the objectives and requirements of the Project, the successful candidates were selected after testing and interview procedures, and then they were delivered a series of induction and sectoral trainings, with Ukrainian reality taken into account. Therefore, some preliminary field observations were made during pre-placement stage in the process of learning the specificity of EU legislation and general features of the documents, as well as during translation and quality assurance stages, practical seminars and workshops on using CAT-tools.

The research data include 96 documents (2616 pages) assigned during February 2017-June 2019. Based on the data of the Project's timesheet reports, the predominant amount of the workload consisted of editing and proofreading activity $(87.5 \%$ of the documents and $87.8 \%$ of the total pages). Occasionally, such activities as translation (10.4\% of the documents and $11.2 \%$ of the total pages) and revision (2.1\% of the documents and $0.68 \%$ of the total pages) were assigned. According to the type of the documents assigned, the workload consisted of directives, regulations, recommendations, communications, notices, guidance papers, strategies, and Association Agreement progress reports.

The bulk of the content referred to financial sector (securities, credit institutions, non-delta risks, interchange fee, ELTIFs, financial instruments); agriculture and food industry (seed, aquaculture, fisheries, feeding stuffs, animal nutrition, animal diseases, feed hygiene); energy sector (spent fuel, electricity market); economy, trade, and public sector (state aid, de minimis aid, aid rules, benchmarks, competition, quality evaluation, personal data); public transport (motor 
transport, water transport, railway transport) and sea carriage (marine equipment, port facility security, ship security, watercraft); environment, security, and medical sphere (organotin compounds, volatile organic compound, medical treatment, hazardous substances, threats to health, cross-border threats); information systems and technologies (RIS, EU digital single market, response system, communication services, rapid alert system); law enforcement (confiscation orders, money laundering, asset recovery offices).

The role of Associate Translation Fellow presupposed not only editing which allowed to identify the most typical mistakes and problems arising from the process of translating an EU-document but also preparing feedbacks about junior fellows' performance, giving guidelines and support for improving the quality of the primary translations. In the course of these activities it was possible to identify the areas of concerns and establish translator's general and specific competences required for dealing with institutional documents as well as to gain the insights into the genre of translation of the EU acts.

\section{Results}

The integrated approach to the study of the nature of the EU legal texts based on the analysis of professional literature and field work at the Project enabled us to reveal the trichotomy of interrelated facets which manifest in formation of the Ukrainian variant of the EU-specific legal genre: cognition-language style-discourse. The findings have been synthesised and analysed, with a range of conference papers [8-11] presented both at academic and industrial translation-related events.

Three major aspects should be brought into focus. Firstly, the analysis of the process of transformation of a source text into a target text shed light on how and to what extent the translated version of a document represents a reality and whether it can be embedded into the Ukrainian legislation. This presupposes that a translator or an editor should take control over their cognition processes in order to avoid conceptual mistakes or discrepancies in construction of the translated document. A cognitive approach was taken to explain the cognitive processes of transforming a source text into a target text in a way that minimises translators' risks of being at a loss or suffering dead-ends, or getting entrapped into misunderstanding of certain facts. Secondly, EU legal discourse must be taken into account, as far as a translated text of an EU act is not merely a text but a document which is actually being discussed, proofread, revised, given feedback, transposed and implemented. Besides, it is a document that is enacted by the Parliament, so it has legal force and effective date. Thirdly, to describe a substyle or a specific genre of institutional documents, traditional stylistic analysis was carried out to analyse equivalencies between the source and target texts with regard to legal and political discourse, sectoral domains, specific technical terms, and overall compositional structure of directives, regulations, decisions, recommendations.

Apart from linguistic features of EU texts and Ukrainian context taken into account, the organisational aspects of translation process at the Project are brought into focus as well. In particular, they include the challenges solved (cognition, ensuring uniform translations) and results of dealing with primary translation prepared by junior specialists with an overview of some typical mistakes.

\subsection{General stylistic features of EU legal texts}

Dealing with original texts, a Ukrainian translator should first of all be aware of the general characteristics the EU language style, the structure of the documents, their rhetoric, and common tendencies in the use of terminology. The review of scientific papers [4-7, 12-15] and the possibility to observe the specific features in the process of working with EU documents resulted in recognition of the basic parameters, which is essential for processing, analysis, and provision of accurate translations in Ukrainian. The totality of specific linguistic features of EU legal documents includes the following stylistic features of institutional translation. Firstly, the texts of acquis communautaire are "EU institutionallegal texts, which are supranational legal documents drafted against the backdrop of socio-cultural differences among the individual Member States of the European Union" [4:161]; secondly, the EU texts constitute "a pan-European text genre" [4:162] predetermined by the features described by Prof. Klaudia Bednárová-Gibová in Acquis communautaire as supranational legal texts and their interlingual reproduction across multilingual Europe, as commented below based on the actual experience at the Project.

These are also "hybrid texts ... as a result of translation process within internationalisation comprising features which are 'strange or out-of-place' for the receiving culture in lexis, syntax and/or stylistics" [ibid]. In other words, the language of a document absorbs some specific features of the culture and language of other Member States, with which translation fellows of the Project have dealt multiple times when translating or analysing original versions of the EU acts.

These are 'reproduced texts which are not based on the semantics of a source text, but on 'linguistic precedent', that is, the surface level of the wording of prior texts and parallel texts" [ibid]. The practice of working with the EU acts in the framework of Association4U Project also implied the situations when for representing the concept of the original version the fellows used other language versions as reference materials in order to find out how this or that term had been previously translated in other EU countries. This was necessary for the most accurate rendering of the intentions and rhetoric of the source texts of EU documents.

The "template-like nature of EU texts is a consequence of the institutional standardisation of their form and language, which is manifested in the creation of a homogenous discourse by the use of identical means of the language inventory in 
the target language, i.e. by imitating (English) originals" [ibid]. Working in the framework of templates, or typical compositional structure, ensured sustainable uniform terminology at various levels of governmental institutions.

After all, EU texts are horizontal, i.e. of the same significance. All language versions have equal legal force, whereas multilingual peculiarities ensure the generalised pan-European worldview, with specific cultural features of individual member States. All the instruments developed in the languages of Member States are formally equivalent [14:17], with plurality and diversity of languages [15:11] taken into account.

Considering the EU multilingualism strategy [16], regulations, directives, decisions, recommendations are developed by non-native speakers of English, which influences grammatical structures used, actual terminological equivalency, clichés, and overall stylistic consistency.

Therefore, the deeper philological expertise and a theoretical review of the nature of the EU legislation provides a clear understanding of the specificity of the texts Ukrainian translators deal with in the process of adaptation of the national legislation to the legislation of the European Union.

\subsection{Ukrainian context}

The Publications Office of the European Union sets forth the stylistic recommendations on each language version in Interinstitutional Style Guide, which provides for compliance and adherence to a uniform standard of linguistic presentation, titles, morphological and syntactical consistency, terminology and clichés. Nonetheless, in the framework of the EU-integration process, each new language faces the challenges of development and establishment of models, terminology, patterns for such new potentially official language on the basis of the texts written in EU languages [17], embracing its grammatical, lexical, and stylistic peculiarities. Therefore, there arises a question of adequacy, accuracy, and homogeneity of translations of acquis communautaire into Ukrainian in the context of language versions of Member States. Thus, in view of the aforesaid, the Ukrainian language is a potentially "new" language of EU developing in the context of EU-integration processes.

The issue of ensuring high quality translations is closely related to the problem of stylistic balance of the final documents submitted to institutions. A uniform style across a system of translation is a key to maintaining the parameters of official genre. "While the word genre more frequently refers to a category of texts than to a set of translations or to the translation process itself..." [13:45], translators face the challenge of development of their own stylistic competence. This challenge implies finding a middle ground between formality and ultimate accuracy, naming the phenomena correctly, avoiding conversational, dialectal, or literary lexical variants, deciding on whether it is possible to use an image bearing language unit for introducing a new term, in particular, in financial and economic sectoral documents, in the situation when stylistically neutral verbal means fail to convey the exact meaning properly. To solve this question, a translator should be able to carry out semantic analysis and be aware of "referential and connotative meanings" [13:34] and adhere to the stylistic parameters of institutional documents.

Based on the analysis of the stylistic peculiarities of EU documents and of the problems of ensuring accurate translations into Ukrainian, close attention shall be given to following aspects: a) the Ukrainian language as a supranational variety; b) normative shifts within the system of the modern Ukrainian language; and c) prospective status of the Ukrainian language in the system of the official languages of the European Union. Since the Revolution of Dignity (2013-2014) in Ukraine the development of the modern Ukrainian language has been constrained by two factors. Firstly, because of the EU-integration endeavours, Ukraine is building up its own "supranational" language of legislation, like it was done by the Member States in due time. The Ukrainian language tends to be influenced by "Eurolect" as a substyle, which is developing through the lenses of acquis communautaire. This specific language of EU legislation is a unique phenomenon, de-cultured and as neutral as possible, which enables communication at pan-European level [6]. Consequently, Ukraine has its own demand for the development of this genre for the language of Ukrainian legislation. Secondly, the development of the institutional Ukrainian language also depends on the official languages of the European Union. Translators shall be aware of the fact that "English and French prevail in all EU institutions, save for the Court, which language is French. It means that other language versions are commonly translated either from French or English. These documents contain the terms of Latin and French origin and archaic terms" [12:46].

The second direction of the latest development of the Ukrainian language concerns the tendency of going to the roots of Ukrainian history: for instance, retrieving Ukrainian historical and literature heritage for enrichment of vocabulary (e.g. місиезнаходження - осідок for establishment [18]), using clichés characteristic of proper Ukrainian language instead of using Russian language calque. Moreover, in the light of the events that took place in Ukraine in 2013-2014 and in view of that the status of the Ukrainian language as an official national language is strengthening, the peculiarly Ukrainian morphology is used more often contrary to the language forms, the use of which had been previously influenced by the Russian morphological language resources due to the post-Soviet linguistic paradigm (e.g. changes in use of suffixes: протиобрастаючі фарби - протиобростні фарби for antifouling composition [19], іонізуючий вплив іонізівний вплив for ionising effect [20]), Thanks to the scrupulous job performed by the Project's senior translation fellows who provided guidance both to associate and junior fellows, the above mentioned morphological and lexical concerns were resolved. The translation variants offered by senior fellows entered the official translated versions of EU documents, which were published and used as a basis for new Ukrainian regulatory acts. 
Therefore, the Ukrainian professional legal and political discourse is being developed through the lens of EU-specific language, which predetermines the formation of a special code for translators and editors to be used in the process of preparation of high quality translations which serve the basis for Ukrainian law making.

\subsection{Challenges met at the Project}

According to the Project's report "Association4U Success Story 01/2016-06/2019", "112 Ukrainian translators and proofreaders, mostly freelancers and university staff were recruited, trained and worked as Project Translation Fellows accumulating valuable institutionalised translation system" [21:4]. Specifically, the description of the position of Associate Translation Fellow included: 1) translating, editing, revising and proofreading the documents related to the implementation of the EU-Ukraine Association Agreement from English into Ukrainian and vice versa using ComputerAided Translation (CAT) software; 2) delivery of translation related training and participation in relevant training; 3) providing summaries of frequent mistakes and problems in translations to Senior Fellows, providing guidance for Junior Translation Fellows; 4) evaluating translation efficiency; 5) participating in trainings, conferences, public events.

Behind the scenes was the work done by the Association4U team based on the principles of interaction and cooperation and a unified approach to the Ukrainian version of translation of the EU acts. The proper organisation of the translation work-flow processes allowed to make timely revisions and corrections, to take the beneficiaries' requirements into account, to improve the editing and proofreading skills and to use the translation memories for consistent and uniform terminology and style of documents.

Apart from organisational and purely institutional aspects, the Project's agenda included linguistic issues of formation of the "supranational" language of legislation [5] from Ukrainian perspective. The major challenges include the issues of cognition and cognitive ability of a translator as an ability to grasp the essence of phenomena and analyse them, ensuring stylistic balance of the translations of EU legislation and understanding discursive character of the translated documents.

\subsubsection{Cognition-related challenge}

The translation process starts with cognition. Cognition is the primary stage of processing an original text, yet the most crucial one because the adequate development of new acts of Ukrainian legislation depends on respective understanding of source texts. The perception of information about the phenomena represented in the EU acts, their recognition and naming in Ukrainian language requires deep background knowledge from translators, proofreaders, reviewers and project managers, acquired in the course of translating activity. However, due to lack of certain EU-related facts, specific institutions and statuses in Ukrainian reality, and, respectively, the terms which would be absolutely analogous or parallel to EU terms, a Ukrainian translator as a linguist performs an important role in development of the nominative aspects of the Ukrainian legislation.

Thus, the first cognition-related challenge concerns a comparative analysis of legislative and actual sectoral reality both in Ukraine and the Member States. If certain phenomena are analogous in both legislative systems, then the translator's experience serves as support for recognition of such phenomena: a translator selects proper terminology easily and finds the ways of adequate nominations. If certain sectoral or legislative phenomena differ, the notions, already formed under the influence of background knowledge of Ukrainian legislation and sectoral policies, must be specified and adjusted. However, when there are no phenomena, mechanisms, rules, and systems in the world view of Ukrainian reality, which would be analogous to those existing in the Member States, new concepts should be built up, with adequate terms and definitions assigned. Realising this, translators should mind their reasoning processes based on the offered mode of actions (table 1).

Table 1. The algorithm to solve the cognition-related challenge

\begin{tabular}{|l|l|}
\hline \multicolumn{2}{|c|}{ Known vs Unknown } \\
\hline Ukrainian reality $=$ EU reality & Applying background knowledge and experience \\
\hline Ukrainian reality $\sim$ EU reality & Adaptation of concepts, approximation of terms \\
\hline Ukrainian reality $\neq$ EU reality & Formation of new concepts and new terms \\
\hline
\end{tabular}

Table 1 shows the algorithm of actions a translator can perform to meet the challenges of understanding the original legislative documents and render equivalent meanings, which ensures accurate approximation of EU and Ukrainian legislation.

The second cognition-related challenge concerns the myth that cognition is reflection of the world. However, translators shall be aware that cognition involves interpretation of the world to some extent. Is actual translation interpretation of the described reality to some extent or absolutely accurate representation of it? The observations made during the period of working as a team member show that every translator perceives the content of the source text based on their background knowledge and experience gained previously in the course of other projects or studies, or collective knowledge, or some crusted professional habits, but always in their individual manner and to the extent of their foreign language competence. The translation component of the Project was teamed up with many experts, each having a professional approach, experience, qualifications, and opinion. They stood out as personalities. 
Yet, the translation of any EU act (regulation, directive, decision, recommendation, or guidelines) must be accurate and must not create obstacles for effective transposition thereof. The team had to achieve consensus on the uniform construction of the terms and provisions on the whole, developing a unanimous vision. In the framework of the Project, fellows interacted first of all at the level of building concepts and sharing knowledge on EU legislative peculiarities in various sectors.

The third such challenge refers to the control of the thinking processes during translation and editing. It is necessary to identify ambiguous meanings, dead-end situations or mental traps in order not to be at a loss. To avoid erroneous understanding, it is critical to take the "diversity of grammar categories across languages" [22:85] into account, because the "differences in the grammatical structures of the source and target languages often result in some change in the information content of the message during the process of translation. This change may take the form of adding to the target text information which is not expressed in the source text. The change of the information content of the message may be in the form of omitting information specified in the source text" [22:86]. Such risks were strictly controlled and eliminated by associate and senior fellows.

\subsubsection{Homogenisation and technology challenge}

Transformation of heterogeneous primary translations, which may be diverse at first as a result of processing information from various sources, into homogeneous texts in the national language is another challenge. This problem is predetermined by the fact that prior to the Project implementation period the regulatory acts had been mainly translated by various agencies, which lead to terminological inconsistencies and heterogeneous verbal arrangement of Ukrainian regulatory acts.

A uniform language style and terminology is an important component of the approximation of the Ukrainian legislation, embracing homogeneity in the use of language units. The key problem here is that the projects of public and governmental significance normally imply involvement of a large number of labour resources, including translation experts with their own professional opinions and established translation practices. Various experts have a somewhat diverse style of writing and translating, differing from each other in terms of grammatical structures, lexical units, and syntactic constructions used.

A concept of homogeneity derives from the media domain, where the heterogeneous messages from various sources coincide in setting up a uniform agenda and in delivering the homogeneous manner of presentation of events [23]. In response to the challenge of dealing with diverse primary versions of translation, the Association4U team developed its own policy setting out the stylistic parameters and quality assurance standards, implemented through style guides and newsletters specifying the terminology as well as some lexical and morphological features of the Ukrainian language.

Apart from the in-house style policy, this challenge was met with the help of CAT-tools, which allowed to achieve a high level of homogeneity across multiple documents. The metaphor of "mincer" may represent this homogenisation process, which means, in this case, the technological process of assurance of stable uniform terminological, grammatical and overall stylistic language consistency through the use of MemoQ program. This CAT-tool facilitated the process of ensuring standardised translation as an end-product to be delivered to the beneficiaries for terminological expertise. As a result, the primary heterogeneous versions made by junior team members were finally transformed into the standardised, well-balanced, and coherent texts of translations.

The MemoQ technology ensured translation memory of all the previously translated documents and their use across junior fellows (who mostly performed as translators), associate fellows (who mostly performed as proofreaders), and senior fellows (who mostly performed as reviewers and project managers). Besides, it provided for the possibility to maintain term bases, write comments during translation and proofreading processes, and use other features as assisting tools ensuring the guaranteed preservation of the structure of the translated text, formatting, adherence to uniform terms and definitions, clichés, set expressions.

The organisation of translation process at Association4U Project with the use of MemoQ technology ensured consistency and accuracy in terminology within the most critical elements in translation projects. CAT tools usually have inbuilt terminology modules or can integrate with external terminology databases. Terms in a term base are often bilingual and sometimes even multilingual. A user can store information such as term description, explanation of the term usage or other grammar related information [24].

The "trediting" (from translation+editing) [25:7] was also possible at the highest level of revision and preparation of translated documents for submission to institutions. Another benefit of using MemoQ lies in that it makes it far easier to work with other MemoQ users and it also has the functionality to deal with files from other CAT tools. This technological means allowed to work with other fellows on the same project assigned, have the latest translations from colleagues and ensure peer review and quality assurance. Apart from language consistency ensured with the help of MemoQ, the program allows to work with various formats (DOCX, *.XLSX, and *.HTML or even more complicated one like *.psd (Photoshop), *.XML-based formats, *.XLIFF or DTP) [24] and deliver the formats in compliance with the requirements of end-users. The quality checks and quality assurance functions allowed to minimise technical errors for better quality across the project's team members. 


\subsubsection{Style-related challenge and feedbacks}

As a result of observations made in the course of proofreading primary translations, a somewhat paradoxical regularity was revealed. Dealing with a large number of such preliminary translated documents, we noticed that it was easier to spot the drawbacks in the lower quality translation rather than in the texts of acceptable quality level. The shortcomings were then more conspicuous due to stylistic and terminological inconsistencies or difficulties to grasp the meaningful parts of primary versions. In this case, the stylistic phenomenon of "foregrounding", known in Stylistics as "the effect of defeated expectancy" [26-27], played out. The perception of such inconsistencies was prolonged and required some extra time and effort made for figuring them out and getting to the heart of the matter. If this is the case, a proofreader should establish logical relations between textual segments and arrive at proper conclusions.

Yet the most challenging was the situation when a translated document seemed adequate in terms of its overall verbal arrangement while the meaningful inconsistencies were almost impossible to notice. Therefore, a proofreader should develop a precautionary attitude to the primary translations of good quality in order to avoid the situations of getting mentally entrapped into misrepresentation of concepts.

To achieve the required level of performance in the capacity of Associate Translation Fellow, it was necessary to carry out a comparative linguistic analysis of the source texts and target Ukrainian texts, with a focus on the stylistic peculiarities in the process of editing the draft translations into Ukrainian. Based on the results of such analysis, feedbacks about typical mistakes were given to junior fellows, as well as general stylistic recommendations were put forward and discussed at the training sessions.

To elucidate some stylistic challenges of translation into Ukrainian, in view of the aforesaid common features of EU documents, we will illustrate some typical mistakes made by junior fellows and possible ways of improvements at the stage of editing. The document was then submitted for final revision and selective check, and later - to the stage of terminology expertise made in sectoral government departments.

The case study of proofreading practice described herein includes three segments (tables 2,3,4) taken from Council Directive 2006/117/Euratom of 20 November 2006 on the supervision and control of shipments of radioactive waste and spent fuel [28].

Table 2. Dealing with semantic shift

\begin{tabular}{|c|c|c|}
\hline Original text & Primary version of translation & Edited and proofread segment \\
\hline $\begin{array}{l}\text { (1) Operations involved in } \\
\text { shipments of radioactive } \\
\text { waste or spent fuel are } \\
\text { subject to a number of } \\
\text { requirements } \\
\text { Community } \\
\text { international and } \\
\text { instruments (2) regarding } \\
\text { in particular the safe } \\
\text { transport of radioactive } \\
\text { material and the conditions } \\
\text { under which radioactive } \\
\text { waste or spent fuel is (3) } \\
\text { disposed of or stored in the } \\
\text { country of destination. }\end{array}$ & 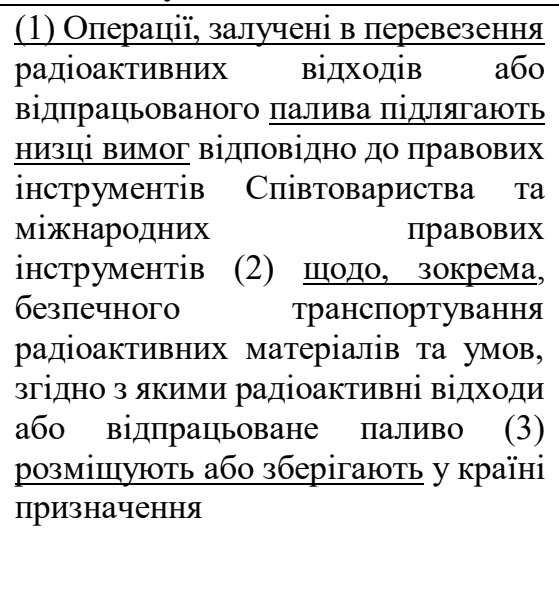 & $\begin{array}{l}\text { (1) На операції, пов’язані } \\
\text { перевезенням радіоактивних } \\
\text { відходів або відпрацьованого палива, } \\
\text { поширюється низка вимог } \\
\text { відповідно до правових інструментів } \\
\text { Співтовариства та міжнародних } \\
\text { правових інструментів, (2) зокрема } \\
\text { щодо безпечного транспортування } \\
\text { радіоактивних матеріалів та умов, } \\
\text { згідно з якими радіоактивні відходи } \\
\text { або відпрацьоване паливо (3) } \\
\text { необхідно розміщувати або зберігати } \\
\text { в країні призначення. }\end{array}$ \\
\hline
\end{tabular}

Table 2 contains three columns, the left one contains the segment of the source text, the middle column demonstrates the draft translation into Ukrainian prepared by a junior fellow, and the right column illustrates the edited version. The most conspicuous drawback of the primary version of translation is its literal wording, which results in semantic shift in terms of categories and leads to misrepresentation.

For instance, (1) "operations" in the meaning of actions erroneously acquire the features of the category "participants involved in the process of shipment". Obviously, in order to improve the text from stylistic point of view, it is necessary to make a transformation for aligning conceptual levels and reorganise semantic roles, as it is illustrated in the edited segment.

Apart from correcting the semantic mistake, the syntactic structures should be revised and re-structured for avoidance of unnecessary accumulation of specifying elements (2) щодо, зокрема. To describe the process of waste disposal, the junior fellow used passive constructions (3) "розміщують або зберігають", which were then replaced with infinitives “необхідно розміщувати або зберігати...” according to the style guide of the Association4U Project.

There are similar shortcomings in the following fragment (table 3), namely, they refer to the combination of lexical and morphological verbal means resulting in misrepresentation of the concept and category of the phenomenon. Thus the abstract idea "protection" acquires the characteristics inherent to the category "entity", which makes it difficult for an end-user to grasp the meaning of the document. The syntactic arrangement of the segment in the primary version is a result of influence of the English language structures of the original text, which is more concise as compared to the Ukrainian language. 
Table 3. Dealing with misrepresentation of concept

\begin{tabular}{|c|c|c|}
\hline & Prim & Edited \\
\hline $\begin{array}{l}\text { Further to these } \\
\text { requirements, the health (1) } \\
\text { protection of workers and the } \\
\text { general public (2) requires } \\
\text { that shipments of radioactive } \\
\text { waste or spent fuel between } \\
\text { Member States and into and } \\
\text { out of the Community be } \\
\text { subject to a compulsory and } \\
\text { common system of prior } \\
\text { authorisation. }\end{array}$ & 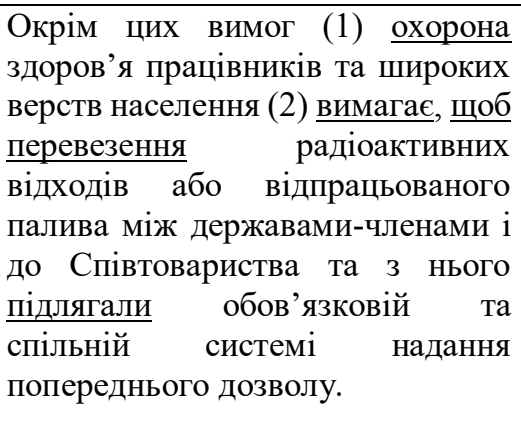 & $\begin{array}{l}\text { Окрім цих вимог (1) у сфері охорони } \\
\text { здоров'я працівників та широких } \\
\text { верств населення }(2) \text { існує } \\
\text { необхідність щодо встановлення } \\
\text { обов'язкової та спільної системи } \\
\text { надання попереднього дозволу для } \\
\text { здійснення перевезень радіоактивних } \\
\text { відходів або відпрацьованого палива } \\
\text { на рівні між державами-членами, а } \\
\text { також у разі їх ввезення та вивезення } \\
\text { з Співтовариства. }\end{array}$ \\
\hline
\end{tabular}

To improve the verbal arrangement and ensure proper rendering of the meaning, it is necessary to rearticulate the fragment of the source text or totally transform it, regulating redundancy as appropriate, as it is shown in the right column (table 3).

The fragment below (table 4) contains the discordant wording due to the use of passive constructions and lack of differentiation of coordinative sentences as a consequence of omitting coma between them and due to lexical and semantic inconsistency (for instance, it is necessary to select a better Ukrainian equivalent than "постачати" to the lexical unit "supplied"). The edited version contains a more acceptable combination of verbal means which ensures appropriate perception and understanding of the document by the experts working in the sphere of shipments of radioactive waste. The improved version has a stylistically neutral wording appropriate for a legal document.

Table 4. Dealing with discordant wording

\begin{tabular}{|c|c|c|}
\hline Original text & Primary version of translation & Edited and proofread segment \\
\hline $\begin{array}{l}\text { The application for authorisation (1) } \\
\text { shall be completed and (2) any } \\
\text { further documentation and } \\
\text { information referred to in Articles } \\
10,13,14 \text { and } 15 \text { shall be (3) } \\
\text { supplied in a language that is } \\
\text { acceptable to the competent } \\
\text { authorities of the Member State to } \\
\text { whom the application for } \\
\text { authorisation is submitted in } \\
\text { accordance with this Directive. }\end{array}$ & 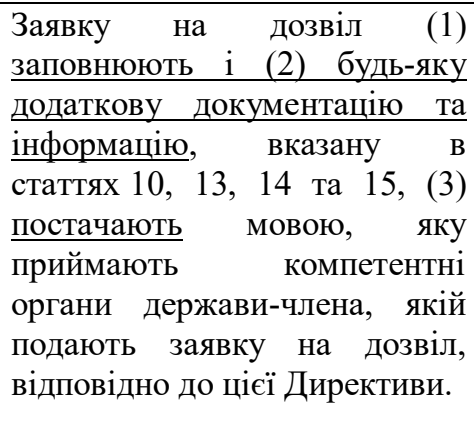 & $\begin{array}{l}\text { (1) Необхідно заповнити заявку } \\
\text { на отримання дозволу та (2) } \\
\text { оформити будь-яку додаткову } \\
\text { документацію та інформацію, } \\
\text { вказану в статтях } 10,13,14 \text { та } 15 \text {, } \\
\text { і (3) подати її мовою, прийнятною } \\
\text { для компетентних органів } \\
\text { держави-члена, до яких подають } \\
\text { заявку на отримання дозволу } \\
\text { відповідно до цієї Директиви. }\end{array}$ \\
\hline
\end{tabular}

In all the cases described above, the stylistic imbalance was caused by the lack of properly organised transformations. Mastering the ability to maintain stylistic balance between two versions of documents must be a priority in development of translators' competence. Another important skill is correcting flaws at the stage of editing and proofreading for the proper preparation of the Ukrainian version of the EU acts for the further revision and terminology expertise stages.

\subsubsection{Matrix of competences}

Based on observations over the quality of preliminary translations and on the results of preparing feedbacks about typical mistakes, the following skills were singled out: legal foreign language terminology and style, establishing grammatical equivalencies between the European English language variety and the Ukrainian language, the ability to construe the meanings adequately, the awareness of the sectoral vocabularies, the ability to search for additional and relevant information, to master computer-aided translation technologies, to work as a team player being able to achieve consensus on disputable and ambiguous questions. As a result, a matrix of the professional competences of an institutional translator was developed (table 5).

Table 5. Matrix of Institutional Translator's Competences

\begin{tabular}{|c|c|c|}
\hline Translation studies & The fundamentals of EU law & Legal foreign language \\
\hline \multirow{3}{*}{$\begin{array}{l}\text { General philological } \\
\text { (contrastive aspects of } \begin{array}{r}\text { background } \\
\text { grammar, }\end{array} \\
\text { lexicology, stylistics, history of the English } \\
\text { language, hermeneutics) }\end{array}$} & Sectoral basic knowledge & \multirow{2}{*}{$\begin{array}{l}\text { Professional } \\
\text { language }\end{array}$} \\
\hline & Legal linguistics & \\
\hline & Industry-specific translation & CAT-tools \\
\hline
\end{tabular}


Table 5 shows a tentative standard of Association $4 \mathrm{U}$ translation personnel. Prior to commencing their duties at the Project, the fellows had various competences based on their educational background and previous experience in the industry. They were complementary as if a puzzle of a collective image of legal translator. In the course of implementation of the Project, fellows had a possibility to enhance and extend their competences due to numerous trainings and discussions held and due to shifting their roles "translator/reviewer/reviser" as assigned.

\section{Discussion}

Other considerations based on the observations made include two directions of discussion with reference to the EU translation into Ukrainian. The first one concerns the parameters of formation of Ukrainian "Eurolect", and the second aspect touches upon the discursive nature of the documents translated within the framework of A4U Project.

Traditionally, translation of EU legislation is referred to as legal style, the issues of which can be resolved within the framework of legal linguistics. This approach sets out the stylistic parameters for using target languages. However, the style of EU documents, in particular, that of preambles, contains political or diplomatic rhetoric. Many provisions are developed as a result of political negotiations between Member States. In terms of Ukrainian reality, the style of EU legislation translation presupposes the emergence and development of the Ukrainian language variety of "Eurolect" both at the institutional level and in mass media. This substyle is characterised by a complex of stylistically neutral lexical units, nomenclature words and terminology, uniform grammatical structures as well as a tendency to simplification of legalese and bureaucratic language clichés. At the same time, the use of specific "jargonisms, or "professionalisms" makes this genre of translation stand out from the typical legal style. Occasionally, metaphors may be used for transmitting some terms. Also, as a result of the linguistic observations made in the course of analysing the original documents, it is possible to affirm that each document embraces some rhetorical message or guidance and obligatory tone.

Another observation concerns the discursive nature of a translated document. As soon as the translation is prepared it becomes the subject matter of discussion. As soon as it is approved and standardised it plunges into the legislative and political world becoming the basis for the development of a new legislative framework of Ukraine. The discursive nature of this process has such features as interrelation with other sectoral documents translated as packages, thematic discussions held at governmental and social levels, for instance, innovation of energy sector, ecology, financial markets, communication in the process of translation, editing and proofreading, selective checks, terminology expertise, both at the internal and external levels of the Project - between Project's experts and specialists of beneficiary institutions, transformation of the heterogeneous versions into a homogeneous and stylistically uniform text of a final translated document which becomes the underlying document for development of new Ukrainian regulatory acts.

\section{Conclusions}

The aforesaid speaks for the importance of the cognition-style-discourse trichotomy to be understood by institutional translators for establishment of the system of high quality translations of the EU acts. A deeper insight into the linguistic nature of EU documents but not only into a freelancer's translation routine is a promising area for exploration of acquis communautaire within the academic domain.

In view of this, the prospects of the further research include empirical study as to what degree young specialists in Ukraine are aware of Eurolect genre and whether graduates from the universities consider such substyle to be political or legal discourse, with a survey to be conducted among graduates of linguistic and legal faculties and statistical analysis of the obtained data. Moreover, freelancing as a fellow at the EU-funded project with an academic mindset provides for the possibility to shift the roles and positions assigned for high-quality career performance and gives Ukrainian translators the hands-on practice and professional experience of working at the level of governmental institutions. The legacy of the first phase of the Project is of great value for the next generation of approximation experts and is viable to be replicated in academic and institutional domains as well as used in other EU-funded projects aimed at enhancing the capacities of Ukrainian governmental institutions.

\section{References}

1. M. Emerson, V. Movchan, Deepening of EU-Ukrainian Relations (Rowman and Littlefield International, Ltd., London, 2016)

2. Law No. 1629-IV of 16/03/2004, OBVRU, 29 (2004)

3. H. Snyder, JBR, 104 (2019)

4. K. Bednárová-Gibová, Procedia Soc Behav Sci, 236 (2015).

5. Ł. Biel, Lost in the Eurofog: The Textual Fit of Translated Law (Peter Lang, Frankfurt, 2014).

6. Ł. Biel, Quality aspects in institutional translation, 31-57 (Language Science Press, Berlin, 2017).

7. Ł. Biel, Legal Translation. Current Issues and Challenges in Research, Methods and Applications, 25-39 (Frank \& Timme, Berlin, 2019)

8. E. Paliichuk, Translation of EU legislation: cognition - style - discourse, in Proceedings of the 1st International Conference on Translation and Language: Comparative Studies, 27-28 March 2019, Kyiv, Ukraine (2019) 
9. E. Paliichuk, Institutional Translation in Ukraine: Challenges, Competences, Prospects, in Proceedings of the 3rd National Scientific and Practical Conference: At the Crossroads of Language and Law, 21 February 2019, Kyiv, Ukraine (2019)

10. E. Paliichuk, Stylistic features of proofreading EU legal acts, in Proceedings of the 2rd National Scientific and Practical Conference: At the Crossroads of Language and Law, 22 February 2018, Kyiv, Ukraine (2018)

11. E. Paliichuk, Challenges of Translation Projects on Support for the Implementation of EU-Ukraine Association Agreement: A Linguistic Perspective, in Proceedings of the International Interdisciplinary Conference on Communicative Discourse in Multicultural Area, 6-7 October 2017, Mykolaiiv, Ukraine (2017)

12. C. Almasan, Translation Practice (Sibiu, 2016)

13. B. Hatim, J. Munday, Translation. An advanced resource book (Routledge, Taylor and Fransis e-Library, 2004)

14. D. Langlet, S. Mahmoudi, EU Environmental Law and Policy (Oxford University Press, Oxford, 2016)

15. P. Ricouer, On Translation. Thinking in Action. (Routledge, Taylor and Francis e-Library, 2006)

16. $\mathrm{COM}(2005) 596$ final

17. L. Cheng, K.S. King, The Ashgate Handbook of Legal Translation (Routledge, L., N. Y., 2016)

18. OJ L 119, 4.5.2016, 1-88

19. OJ L 115, 9.5.2003, 0001-0011

20. OJ L 81, 21.3.2012, 7-17

21. Association4U Success Story 01/2016-06/2019: a final public report, (2019)

22. M. Baker, In Other Words: A Coursebook on Translation (Taylor and Fransis e-Library, 2001)

23. L. M. Bartels, APSR, 87(2), 267-285 (Cambridge University Press, Cambridge, 1993).

24. Why use CAT tools? An Introduction to Computer-Assisted Translation: an eBook (2021)

25. Studies on Translation and Multilingualism: a brochure (DGT, Brussels, 2009)

26. D.S. Miall, D. Kuiken, Poetics, 22(5) (1994)

27. W. van Peer, Stylistics and psychology: investigations of foregrounding (Croom Helm, London, Sydney, Wolfeboro, New Hampshire, 1986)

28. OJ L 337, 5.12.2006, 21-32 